\title{
"The Whole Feminist Taking-your- Clothes-off Thing": Negotiating the Critique of Gender Inequality in UK Music Industries
}

\author{
Toby Bennett \\ Solent University \\ toby.bennett@solent.ac.uk
}

\begin{abstract}
This article considers the critique of inequality, exploitation and exclusion in contemporary UK music industries, in light of the latter's growing internal concerns over work-based gender relations. The creative sector's persistent inequalities are at odds with its professed liberal, egalitarian, meritocratic values and attitudes. Yet, within music's industrial production cultures, a dismissive postfeminist sensibility has come under pressure through a reflexive critical moment of popular feminist discourse, expressed in trade press critique, between 2013 and the present moment. Drawing from a study of intermediary work in UK major record labels, the article takes a pragmatist approach to documenting and theorizing this critique - alongside institutional mechanisms, like company policies and corporate PR, that respond to it - in terms of growing industrial reflexivity. Tensions over the representation of work, the nature of inequality, intergenerational and epistemic injustice emerge as key themes, with implications for critical research on popular music industries.
\end{abstract}

KEYWORDS: Creative labour, Inequalities, Industrial Reflexivity, Major Record Labels, Post-feminism.

\section{Introduction}

Between 2007 and 2016 I circulated in and around the UK's major record labels. First, as an employee in a rights licensing role; later, researching transformations of professional lives in that context, after so-called 'digital disruption' (that is, in a period of emerging political-economic stability, after disruptive tendencies associated with new technologies of production, distribution and consumption had temporarily threatened the market hegemony of mainstream recorded music 
companies). Specific subject positions were not initially a focus of the research project. Nonetheless, issues of gender became unavoidably pertinent to the research, when inequalities began being raised seriously and regularly in music industry trade and consumer press in what might be called a critical moment, beginning in 2013, which became, potentially, a new moment of crisis. Although rarely raised in interviews, one wincing and exasperated Corporate Communications executive, Alan, advised me not to pursue "the whole feminist taking-your-clothes off thing", in any case, "I'm sure a lot of people have already written on it" (Alan 2014). The relationship between industry, critical commentary, and institutional responses to that commentary bears further reflection.

One effect of this critical moment is to provoke consideration on recent material changes in the (recorded) music industries - beyond the creation and reception of cultural objects and broad-scale political economy, to a wider palette of intermediaries - in dialogue with scholarship on inequalities in creative labour (Oakley and O'Brien 2016), particularly that which foregrounds a "postfeminist" sensibility (Conor et al. 2015; Gadir 2017; Gill 2007; McRobbie 2016). This article explores the tensions and continuities between intermediaries' appeals to market logics and egalitarian, meritocratic values and a set of critiques advanced in line with a rising popular "post-postfeminism" (Gill 2016). I first develop the key terms and methodological issues, associated with researching the entwinement of culture and gender in recorded music's "production cultures" (Caldwell 2008). Turning to the origins and development of the critique, I give further consideration to Alan's comment before analyzing industry accounts using four core themes: the representation of work; the nature of inequality; disputes over generational injustice; and the epistemic injustice caused by uncertain knowledge. This analysis suggests that conditions of knowledge production are more broadly patterned by gender. While my intention is largely descriptive, my hope is that the approach taken, and conclusions reached, prove conceptually generative for future scholarly research on popular music industries.

\section{Postfeminism, critique and production cultures}

This article's objective is to describe and critically assess how gender inequalities are articulated within contemporary recorded music production cultures, in the context of debates over postfeminist media cultures. Briefly, in Gill's (2007) articulation, the term diagnoses a sense of feminism's historical displacement: she describes a "postfeminist sensibility" as an orientation to feminism that acknowledges the battles that have been won to recognize women's rights, whilst simultaneously relegating them to the past, and so disavowing the necessity of feminism in the present. Feminism is thus "taken account" of in order to be "undone" (McRobbie 2008), replacing emphases on structural modes of inequality and exclusion with expressions of individualism, consumer choice and self-monitoring (Gill 2017: 613). Resisting this linear narrative, a postfeminist analysis, therefore, attempts to gain critical purchase on empirical reality, diagnosing how practices of account-taking and disavowal play out in different cultural and media formations. Yet, in recent years, feminism has experienced a renewed popular visibility, even luminosity, in media representations, suggesting a fashionable, activist-inspired "post-postfeminism" (Gill 2016: 614). Against this (again) misleading chronology, Gill (2017) argues for postfeminism's continued 
conceptual relevance for understanding evolving and differentiated expressions of both gender and inequality.

Here I pay attention to how postfeminist sensibilities orient (news and commentary on) what, in screen industries contexts, Caldwell (2008) calls "production cultures": that is, professional worlds within the recorded music subsector, rather than the representation and reception of the subjects and objects it produces (important though the latter certainly are). Music's industrial production cultures circulate conventions, discourses, styles and practices, binding personal, social and professional dimensions across a range of spaces (offices, gigs, pubs, conferences, awards ceremonies, texts, social media) and intermediary occupations. Beyond writing, recording and performing artists, the latter includes A\&R executives, managers, promoters, producers, engineers, business affairs and finance representatives, product managers, production coordinators, communications managers, rights administrators, data analysts, PAs and other support workers. Trade press news and commentary is pitched at this scale, not simply delivering information, but informing the common-sense behavioural norms and socially liberal values (diversity, tolerance, talent-based meritocracy) with which music professionals, like those in the creative economy more broadly (Gill 2014; Taylor and O'Brien 2017), are typically thought to align.

The paper documents and theorizes a rise in critical spirit, reading the broader shift in popular feminist visibility through music's "industrial reflexivity" (Caldwell 2008): institutional mechanisms of self-knowledge production. Critique is understood as the voicing of felt injustice with regard either to general ethical principles (for example, equitable gender relations) or specific institutions' internal standards (Boltanski and Chiapello 2005: 32-33). Broadly, participation in cultural and creative production is seen as egalitarian insofar as, as the actress Joanna Lumley put it, "[p]eople who are in our profession don't have those discriminations"; you can "hang out with the boys in the band" while also "part of the sisterhood" (in Taylor and O'Brien 2017: 27). Discourses like this legitimate a sensibility that views feminist concerns as irrelevant or outdated, disavowing the inequitable realities of working experience - which are not unrecognized but rendered "unspeakable" (Gill 2014). Entwined in cultural-economic shifts and gendered social dynamics, music industries stand accused of failing to live up to their professed cultural values.

Two caveats are required. First, inequalities are not just discursive. They manifest through specific labour processes and conditions, in specific workplaces and national contexts. The stable employment opportunities and benefits (such as maternity leave) offered by UK major labels, for instance, are rare in uncertain and changing labour markets. They also propagate jobs in administration and PR that preserve a normative feminine coding (Hesmondhalgh and Baker 2015; Leonard 2014; Parsons 1988), with office environments characterized by clubbable homosociality and juvenile laddish banter (or female feistiness) (Negus 1992: 56-61). Such a context informs my later discussion - though there is not space here to further unpack the consequences of organizational and industry structure. Briefly, the material and the discursive realms are co-constituted in production cultures; music professionals navigate both at once, as they make (sense of) their careers within these industries.

This informs a second caveat. Moving behind the domains of consumption and representation, I nevertheless want to highlight how these domains texture, and are textured by, intermediaries' working lives. That is, "cultural products matter", as Oakley and O'Brien (2016: 473) note, "because they shape how we 
understand ourselves and our society and thus the question of who gets to make cultural products is a profoundly relevant one". The relation is dialectical. Music industry intermediaries justify and valorize career choices in terms of appeals to consumption, that is as fans (Cluley 2013), drawing on such experiences in their professional self-identity and ethical prescriptions (Gadir 2017). The "passion for music" extends to non-creative or support roles, which are similarly embedded in and constituted through music production cultures - even if their work is typically rather more mundane and routinized (Bennett 2018b). It is in this dialectical sense that news reporting and journalistic accounts intervene in the industrial reflexivity of contemporary music industries.

\section{Popular music's industrial reflexivity}

Industrial reflexivity describes how, in Caldwell's (2008) words, production cultures foster "self-theorization": individuals exchanging "trade stories" for "career capital"; or formal institutions assembling knowledge across a range of texts, events and professional rituals. Ways in which popular music's culturalindustrial formations are made knowable - say, popular biographies (Frith 1983) or industry conferences (Let's be the change, n.d. web source) - are strongly gendered, preserving hedonistic or transgressive mythologies of heroic, nonconformist 'record man' figures (Barnett 2014). Popular industry histories valorize a masculine mythos of success and excess - captured in the punning title of one of this genre's most well-regarded books, Hit Men (Dannen 1990) - telling tales of corrupt or exploitative behaviour, commonly justified with a utilitarian ethic: ultimately 'great music' got made. Such texts craft a canon of ideal-typical subject positions for contemporary intermediaries to occupy (Conor 2014), informing expectations over disposition, behaviour and career trajectory.

It was ever thus. Industry histories and aesthetics, expressive styles and resistant subcultures, have long been discussed in predominantly masculine terms (McRobbie 1990). Nonetheless, the music sector's potential for industrial reflexivity has expanded in recent years - evident from such trends as a flourishing of higher education courses, a buoyant trade press, an increasingly active conference circuit, the rise of (big) data-driven market research and evidence-based policymaking (Bennett 2015; Cloonan 2007; Cloonan and Hulstedt 2013; Redmond 2017). Industry-specific trade media facilitates professionalization: curating disciplinary knowledge to construct professional roles (cf. Edwards and Pieczka 2013), and infusing a discursive field of industry reporting, policy research, and conference addresses. These can be read as a set of "semi-embedded textual activities", which primarily "function as forms of symbolic communication between media professionals" - especially "institutional dialoguing between media corporations and trade associations" - while remaining visible within "the public sphere of the consumer" (Caldwell 2008: 346). Their import is felt well beyond the formal, corporate end of the sector, where independent musician-entrepreneurs refashion amateur expertise for professional careers, while a "supplemental industry" furnishes this market with blogs, books, professional training courses and accreditation (Haynes and Marshall 2018: 463).

Rather like the management handbooks analysed by Boltanski and Chiapello (2005: 29-30, 57-60), these textual activities create spaces of negotiation: between mechanisms of capital accumulation and labour-market organization; and critiques of capitalist forces, through which disputes over the justice of such mechanisms are voiced and crystallized. Fraser (2013) describes how some 
aspects of women's emancipation, including critiques of the normative domestic relationships underpinning mid-century workforce participation, have facilitated capitalist reinvention. Likewise, Gill (2017: 611) views postfeminism as the gendering of a "neoliberal" economic logic, characterized by "dynamism and adaptability", warning that it can "change and mutate in relation to new ideas". Intermediaries, at the nexus of countercultural critique, aesthetic innovation and consumer markets, are perhaps primary subjects of such dynamism (McRobbie, 2016), potentially working both to legitimate and resist critique of gender inequalities - at any rate to negotiate it - in line with an evolving "spirit of capitalism" (Boltanski and Chiapello 2005; Fraser 2013). Perhaps popular music's industrial reflexivity increasingly institutes critical self-analysis at the heart of music's production cultures. If so, what is the nature of this analysis?

\section{Methods and approach}

The paper stems from a qualitative research project which took place between 2012 and 2016, informed by my own professional history in a major label (20072012) and as a researcher engaging in ongoing knowledge-exchange activities with industry communities. Thus fieldwork (2013-2016) took the form of: autoethnographic reflection on full membership in that particular production culture; periods of more directed participant observation; and interviews with twenty-three music intermediaries. Part of this immersion involved regular collection and reading of a range of "semi-embedded texts" (Caldwell 2008), providing source material for the following presentation and informing comments on its reception. Popular and trade press have elsewhere been used to register industrial shifts (Conner and Jones 2014; Edwards and Piezcka 2013) - but my approach differs. I do not perform a discourse or content analysis on the sample and am relatively unconcerned with its representativeness. Source selection is more symptomatic than systematic. Informed by a pragmatist "sociology of critique" (Boltanski and Chiapello 2005: xi), I assume that distinctions between kinds of knowledge - workers' situated expertise, academic research, journalistic reporting - are produced by normative practices and institutions, rather than existing a priori. Consequently, material was selected in terms of apparent pertinence within the production culture of which I was a member: being shared around an office, for example, or on social media; or for inclusion in media monitoring and news aggregation platforms like Record of the Day.

The diversity of sources is itself indicative of the critique's reach (as well as shifts in trade press). Much material originates in dedicated print and online publications active in the British context, like Music Week, Complete Music Update and Music Business Worldwide, as well as (the US-based) Billboard. Mainstream newspaper reporting is also present: for example, The Guardian (which, between 2008 and 2012, ran a "Behind the Music" series, penned by the journalist and songwriter Helienne Lindvall) or newer platforms like Vice Media's dedicated music news channel Noisey. Elsewhere, press releases from government or industry bodies like PRS and UK Music provide indicative institutional responses. What counts as relevant knowledge is thus determined by industry norms, not the researcher. Consequently, these texts are not treated as windows onto reality (cf. Wilkinson and Merle 2013); at least partially, they construct that reality. I assume trade media both describes how gender relations and inequalities play out (and why they matter) and offers a discursive resource for workers to negotiate them in practice. 
My analysis addresses the internal coherence of this critical moment, as a (post)postfeminist stance (Gill 2017) on situated inequalities: how gender shapes intermediaries' working lives, rather than artists' creations and careers. Because gender was not the initial object of the research, to an extent my analysis is retrospectively opportunistic, occasioned by a level of serendipitous immersion in the field. Only one interviewee, Alan, ${ }^{1}$ specifically raised the broad-level critical discourse. The next section situates and unpacks his comments, sensitizing the reader to how critical perspectives are received and negotiated by the individuals and companies who are agents of change. It therefore cautions against scholars taking this genre of material as an accurate reflection of industry's strength of feeling and direction of travel on the ground. The following section continues the development of this narrative chronologically. The four analytic themes I subsequently identify, informed by feminist media studies, emerge from this material.

\section{A critical moment}

\section{3-2014: The whole feminist taking-your-clothes-off thing}

In 2013, public debate was kindled over the appearance of what Annie Lennox described as a "spate of overtly sexualized performances and videos", which she considered a "monetized form of self harm" (in Brady, 2016: 436) - most prominently, Miley Cyrus' "Wrecking Ball" (Cyrus 2013) and "Blurred Lines" by Robin Thicke and Pharrell (Thicke 2013). The ensuing public furore saw government announce intentions to give music videos age ratings. While, at a time of concern over university campus "lad culture" (Phipps et al. 2018), several student unions went further, banning "Blurred Lines" for its video's cynical, if (in its director's words) self-consciously "fucked up (...) meta and playful" (Ducker, 2013) deployment of female nudity, alongside lyrics that appeared to sanction sexual harassment and potentially rape. The UK music industries' self-reporting also raised questions of industry's role in representing misogyny, quickly moving to discussions of a "behind the scenes (...) gender imbalance" in work (CMU Editorial, 2014) that dovetailed neatly with another, more established, debate around internship and recruitment practices. The latter were blamed for entrenching the sector's lack of diversity (particularly around class and ethnicity) by "excluding those that may be the most talented but can't afford to work for six months to a year unpaid" (Lindvall, 2013).

Although I did not intend to foreground such matters in empirical research, the absence of direct commentary from interviewees became increasingly troubling when, for example, practices they designated sexist, ageist or otherwise unjustly exclusionary were raised in informal conversation, after the voice recorder was switched off. Alan, a junior Corporate Communications executive interviewed in early 2014, was the exception to the silence when, in a comment on his employer's responsibility towards equitable representation - what he dismissively called "the whole feminist taking-your-clothes-off thing" - he advised me to avoid this territory: "please don't follow that one, it's slightly... I'm sure a lot of people have already written on it!" (Alan 2014). Clearly, my interviewees were not mere data sources. They had opinions on what was and was not (should and should not be) of academic interest. I was encouraged to produce my own silences.

Alan's comment arose through reflections on an episode at a university careers event: a company representative had faced students' indignation over music videos. Events such as these were part of the company's new Corporate Social 
Responsibility (CSR) agenda to support skills development and reach out to the public - and so intervene directly in industrial reflexivity:

\begin{abstract}
Ask us anything, we'll find an answer for it (...) you know, we're a big company, so we have to deal with all these issues. Very very unlikely that a nineteen-year-old student at whatever university they're at is asking something that we as a company haven't possibly encountered previously. (...) If you get a group of a hundred students sat in front of you, who are engaged in music and are genuinely interested, you know, it's a stimulating discussion - 'cos it is always a two-way discussion. It's as important for them to tell us what they think as it is for them to listen to what we think. We are a consumer-facing business at the end of the day. (Alan 2014)
\end{abstract}

This emphasis on students' active inquiries (of any kind) as evidence of "engaged" consumers helped Alan to frame the complaint about exploitative representation by placing emphasis on the autonomy of both artists and consumers. "We can't stop them", he argued of the former, "they are their own entity"; likewise, "our actions as a company are led by what the consumers want" (Alan 2014) - given market forces (and alluding to the new music video ratings), the company is likely to push a more censorious stance. This he caricatured as: "put more clothes on please, your audience is a load of twelve-year-olds (...) if you get your nipples out in a video and that puts a load of mothers off across the country, you really ain't helping yourself". Thus, moral responsibility is outsourced to creators and audiences, while the company is apparently rendered powerless: "we're not doing things because we want to do it, we're doing it because the consumers are asking for it" (Alan 2014).

How do we understand Alan's advice? At one level, given that he himself described his role as "perception management", it is unsurprising. His intuition regarding academic treatments of gender issues ("I' $\mathrm{m}$ sure it's already been written about") is loosely correct - the cultural import of a postfeminist sensibility, channelled through media texts such as music videos, is well understood (e.g. Brady 2016) - but this hardly negates the need for continued attention. Scorning such issues for having already been dealt with, exhibits, if not outright deception, then certainly a strategic "gender fatigue" (Gill et al. 2016). However, although he was clearly conscious of his institutional role as spokesperson, referring often to "we as a company", this hardly exhausts his position. Elsewhere, his conversation pulsed with genuine enthusiasm for colleagues' investment in "a wider love of music" and personal involvement in supporting musicians outside a corporate day job. No mere receptacles of capitalist interests, these workers were passionate, engaged music fans: intelligent, reflexive, often inspiring. Acknowledging that "a big company" has "issues" that "we have to deal with", he roundly rejected accusations of deliberate commercial manipulation. In his view, this was a "false image", embodied in "things like X Factor and Simon Cowell".

Alan presents a case study in reflexive work at the nexus of production, representation, promotion, commitment and knowledge. Partly because his job is to respond to and intervene in industrial reflexivity and partly because of his personal commitment to his colleagues and industry. Of course, his picture of intermediation as a purely benign conduit between fans and artists is clearly idealized, disavowing the more diffuse, cultural-material processes through which gender relations take shape, within the organization and broader professional world. Yet, it also seems difficult to dismiss his inference that - because production cultures, especially those intermediaries who occupy and sustain 
them, remain poorly understood by the outside world - I, a researcher, am obliged to accurately represent the values and passions of industry actors, and the felt meritocratic context in which they produce knowledge. Ultimately, such comments suggest that reflexivity does not simply enable critique of gender inequalities to gain visibility. It conditions how they play out, may even be resisted, amongst relatively sympathetic and thoughtful industry representatives. This insight informs the presentation and analysis, as it continues.

\section{4-2018: Industry reporting}

The trade press did not follow Alan's recommendation. The events of 2013 and 2014 appeared to mark out a rare critical space within industry circles, enabling individuals to voice concerns over previously sensitive and controversial subjects. Routine top lists of influential industry personnel in trade publications like Music Week and Billboard came under pervasive fire for all but ignoring female and BAME executives, as did the Brit Awards (Bernard 2016; Forde 2016), alongside exposés of industry's tolerance of sexual harassment and poor mental health amongst its workforce (Almeida 2015; Gross and Musgrave 2017; Zadeh 2016). Further articles probed into mechanisms for proliferating homogenous monocultures, such as recruitment practices (Jones 2016b) and all-male conference panels (Baker 2016). In 2017, the enormous publicity around a culture of sexual harassment within Hollywood, generated by the allegations faced by Miramax producer Harvey Weinstein (BBC 2017), and the far broader \#metoo campaign, spread to other industries including music. A letter signed by 2192 women in the Swedish music industry (closely linked to that of the UK) testified in November to a "behind the scenes" culture of "assault, sexual harassment and a sexist jargon" (Dagens Nyheter 2017). That year ended with a short documentary, aired on BBC television, exposing a similarly "endemic" atmosphere of "sexual assault and abuse" (Mackenzie 2017).

Institutional Equality and Diversity (E\&D) responses began to emerge - CSR initiatives driven by reporting, rhetoric and legislation emerging from state agencies (CC Skills 2011; HMRC 2014), in the wake of changes in the Equality Act (2010) outlining protected characteristics in greater detail (cf. DCMS 2008), as much as internal critique. The Fair Access Principle campaign was launched to improve recruitment practices at a variety of levels across the creative economy (Creative Society 2015). While the BPI committed to reshaping the Brit Award nomination system to improve diversity (Ellis-Petersen 2016), Music Week launched a dedicated Women in Music awards in 2014, aimed specifically at executives (Women in Music n.d.), and global female peer-support networks were established to promote awareness, role models and job opportunities (Girls I Rate n.d.; Let's Be The Change n.d.; shesaid.so n.d.). Efforts have particularly been mobilized through the work of UK Music, the sector's lobbying body, whose Diversity Task Force responded to the Equality Act (see UK Music n.d.) publishing an Internship Code of Practice, in consultation with the campaign group internaware, and an Equality and Diversity Charter; as well as running a Meritocracy Dinner Series and recommending HR best practices for music companies, such as E\&D representatives and unconscious bias training.

Perhaps their most significant intervention came through undertaking a diversity survey - a data-collection exercise promoted through member organizations and trade press - significant both as a serious attempt to address these issues with quantitative research and because its results were then included 
in the body's economic estimates, which are used by government (UK Music 2017: 17). The survey's summary statistics, indicating that women across the sector are skewed towards the younger cohorts (under thirty-four) and entry-level positions (UK Music 2016), echo earlier findings from the sector skills council (CC Skills 2011) and contemporary internal reporting from industry bodies such as Performing Rights Society (M 2017). Government requirements that all large organizations provide information on their gender pay gap prompted similar proportions amongst the majors' workforce, which reported women's average salary to be $33.8 \%$ lower than men's (Jones, 2018). Such figures, now routinely being cited, are relatively embarrassing for industry representatives. Unfortunately, raw data and methods remain proprietary and inaccessible to further analysis.

\section{Negotiating critique}

The accounts discussed above reveal how gender equality is approached by a range of industry representatives, shaped by four key themes: the representation of work; the nature of inequality; intergenerational injustice; and epistemic injustice. To the extent that they relate to broader social concerns, they reflect recent discussions in feminist media studies and critical scholarship on cultural work, introduced earlier in the paper. These theoretical accounts inform the following analysis, which nevertheless remains situated in the specific professional and industrial context of popular music.

Turning to the first theme, the representation of work, the discourse on gender equality shines a rare light behind the scenes of music industries. Critique does not just highlight the treatment of artists (or even elite A\&Rs, producers and executives) who tend to occupy public interest. It covers a much wider range of intermediaries. This grouping of performers and songwriters together with managers, executives and interns is relatively novel. Although initiated by the reception of certain cultural texts (music videos), critique was accelerated by public acknowledgement of unfairness over issues of pay, alongside a range of gendered exploitations. To use Nancy Fraser's (2013: 193) "three-dimensional" formula of justice: there is now tangible "recognition" of inequality and marginalization of certain groups in music, attached to questions around economic "redistribution". Implicitly, therefore, the possibility of political "representation", at the level of a collective labouring identity, can be raised. Whether "controversies like that which surrounded 'Blurred Lines' help or hinder in that process" (CMU Editorial 2014) remains in question. In interviews, behindthe-scenes music workers (like Alan and colleagues) might express frustrations towards misrepresentation in shows like $X$ Factor - but they rarely identified themselves as part of a collective of workers. Furthermore, no representative body (equivalent to the Musicians Union or Featured Artists Coalition) exists to negotiate or organize on their behalf. While some \#metoo commentators made the relationship between sexual harassment and work explicit (for example Abrahamian 2017), this connection remains obscure in music contexts. The rise of fair access schemes and E\&D frameworks suggest that institutions recognize inequality only as a motor of broad professional formalization. Any politics of collective representation is relatively embryonic and fragile.

This relates to the second theme, the nature of inequality. While a broad industry problem is recognized, responses to it bear different emphases. Much reporting of sexism and harassment quickly moved from a narrative of individual 
monsters to an endemic misogyny or industry culture bolstering professional power imbalances. If this suggests a need for better sectoral and institutional governance, most of the proposed solutions are at the level of individual practice and disposition. Many initiatives centre on inspiring gender parity through media representations and visible female leadership roles (the common refrain: "if you can't see it, you can't be it') or a positive and upbeat "turn to confidence" (Gill et al. 2016: 16), where female executives urge others to speak up (Baker, 2016). Although identifying oneself as a feminist is permissible, doing so in a negative manner is not. In the world of Corporate Communications, students' angry complaints are neutralized as the "stimulating conversations" of "engaged" consumers (Alan 2014). Likewise, in opinion pieces, women are advised by highpowered female leaders not to discuss gender issues in the office, which can easily "sound like a whinge", because "[y] ou have to make your own destiny, create your own boundaries" and "keep going" (quoted in Jones 2016a). Likewise, "[i]f you don't want a glass ceiling, then open your own fucking company" (quoted in Newman 2017). Hence the critique polices affective responses, so that "women must disavow - or at least render palatable - a whole range of experiences and emotions - notably insecurity, neediness, anger and complaint" (Gill 2017: 619). The positivist language of "unconscious bias" has become common, drawing from behavioural psychology that seeks to engineer changes in thinking at the individual level (Jones 2016b). In such ways, "inequalities in organizations are acknowledged rather than denied, yet the need for structural change is disavowed" (Gill et al. 2016: 16); while "the tendency for policymakers in particular is to focus on technocratic solutions to specific manifestations of inequalities, rather than the considerably more difficult work of addressing such inequalities" (O'Brien and Oakley 2015: 15).

Equally, an overwhelming focus on gender is not necessarily unifying (Adkins and Skeggs 2004). Inequalities are patterned by class, sexuality, ethnicity, disability and other structural exclusions, while E\&D initiatives tend to perform "happy talk" - positive stories that celebrate vibrancy and obscure dissonance (Ahmed 2012) - here often tied to a "passion for music" (Bennett 2018a). So, the iconic indie Rough Trade is praised for its female-skewed workforce, but owners Jeannette Lee and Geoff Travis both actively distance themselves from positive discrimination policies, emphasizing that they have "simply employed the best people for the job". The owner of the Visible Noise label, meanwhile, regrets that she had "wanted to employ more women, but the fact was that most of the ones applying for the jobs had not been as fiery and dedicated as the men" (both quoted in Lindvall 2010). Broad notions of workforce equity are thus subordinated to enigmatic character traits which signal individuals' dispositions and commitment to music's emotional, cultural and expressive value. Preparedness to trade low wages and career instability against these same qualities (McRobbie 2016) is naturalized in an ideal (gendered) subject, obscuring the differential distribution of power across intersectional lines (Gill 2017).

The third, perhaps most obvious, theme is that of intergenerational injustice particularly evident in discussions of so-called millennials: those whose formative years came after the year 2000. Many of the articles embroil gender in generational conflict: whether in the dispute over sexual agency and selfexploitation between Sinead O'Connor and Miley Cyrus (Brady 2016), or in terms of an old boys' network of pale, male and stale baby-boomers (Forde 2016) (born in the decades following the second world war) who now need to "make way for a new generation" (Ellis-Petersen 2016). Productive generational accounts evoke the distinct historical (objective) circumstances through which awareness of 
shared (subjective) experiences is developed (Mannheim 1952), to pose longitudinal questions - how, for example, the intense attachments formed during the formative passions and mediatized experiences of late adolescence are carried into adulthood (Bennett 2013; Bolin 2015), through shifting political economies (in and beyond music industries). Conversely, notions of generational displacement, so central to postfeminist discourse (Gill 2007), tend to deploy these labels as marketing devices not as critical concepts. These stage a clumsy and reductive epochal battle (Winch et al. 2016): an older generation, labelled out of touch, pitted against the apparently superficial, consumerist approaches to identity and sexuality (said to be exemplified by current students).

Suppressing intragenerational unevenness in the present, the exaggerated sense of epochal change also risks investing unrealistic hopes for the future in the young. Celebrations of entry-level gender parity in institutional workforce monitoring - as "positive green shoots" that prove "the gender gap is narrowing" (M 2017) - are optimistic "progress narratives" that imply "equality is somehow inevitable and requires no active intervention" (Conor et al. 2015: 7). They conceal, even reinforce, other dynamics through which young women are filtered out while (white, able-bodied, relatively affluent) men tend to endure (Jennings and Gardner 2012). Moreover, epochal accounts betray a poor sense of history. As music supervisor Michelle de Vries reflects: "I thought I was a hangover of the 80 s and 90s, but it's very clear that this behaviour is still going on and young women are being sexually assaulted, still, today" (quoted in Mackenzie 2017). Highlighting a period and a location - media production cultures of the 1980s and 1990 s - that acted as a crucible of postfeminist sensibilities and new masculinities (Gill 2003; Mort 1996), she points to a need to evaluate continuity, as well as change, in relation to popular music's institutional present. This extends into a contemporary need to "think together the rise of popular feminism in tandem with rapidly intensifying misogyny", of lad culture and online trolling, for example (Gill 2017: 611), informing (post-)postfeminist masculinities.

Given rising industrial reflexivity, a fourth theme concerns what could be called epistemic injustice: who decides what and how knowledge is made public (or explicit) or remains private (or implicit)? Even granting that inequalities exist within music industry worlds, registering, diagnosing and describing them is not a simple matter, either for researchers or practitioners. Solid data on inequality in creative industries is inaccessible, difficult to read, or simply does not exist (O'Brien and Oakley 2016: 12-13), indicative of a historical lack of interest in gender inequalities from government and industry bodies (Conor et al. 2015: 6). That government turns to industry to self-monitor (for example DCMS 2015: 37) is equally problematic, given researchers' restricted access to data beyond headline figures. While industry's own workforce reporting is embarrassing therefore, its proprietary nature enables institutions to frame their own narratives and manage the crisis, to an extent. There are further issues over how to interpret the figures and stories that continue to pile up as evidence against the sector. Therein lies the crux of Alan's concern over my role as a researcher: both in his corporate role in "perception management" but also in his private will to communicate employees' genuine passion for music and their profession.

There is an imperative, following feminist research principles, to produce knowledge about creative industries that can be used by those affected (Wreyford and Cobb 2017) but a lack of public data weakens understanding of structural employment issues, collective identity and representation. Much commentary on \#metoo highlights the disclosure of actions by individuals that were previously 
hidden (if not completely unknown), especially the bravery and enfranchisement of such disclosures in the face of powerful networks and legal procedures. Similarly, efforts to enable women and other marginalized groups to develop public speaking roles (in conferences and seminars, for instance) exposes tensions over emerging professional expertise, particularly the legitimacy of certain groups to dominate production cultures and shape common professional understanding. Sector-specific iterations of the \#metoo campaign might be viewed in that light: crowd-sourcing qualitative data to quantitatively evidence anecdotes in the absence of official statistics. Finally then, despite their painful character, such data collection suggests a joyful moment, wherein naming, documenting, cataloguing, and archiving incidents furnishes a sense of scale, conviction, and ultimately hope (Ahmed 2015).

\section{Concluding comments}

Alan's (clumsy) moral defence of industry practice, from the perspective of Corporate Communications, contains aspects with which popular music studies might sympathize. Indeed, the structure of his denunciation - of hypodermic models of media transmission and moral panic, mechanically linking exploitative media content to manipulative intent (on the side of production) and degenerate behaviour (through consumption) - is familiar from forty years of post-Adornian cultural and subcultural studies. In Alan's voice, it has relocated from the scene to the global corporation, shadowing the movement from "clubs to companies" (Alan 2014) which, McRobbie (2016: 20) explains, translated "elements of youth culture, in particular those drawn from the energetic and entrepreneurial world of dance and rave culture" into the fractured, self-marketed world of the creative economy. Earlier, McRobbie (1990) had advanced a critique of her peers' writing on subcultures for their constitutive gendered absences: perhaps this too has moved to the workplace, reprised in the critical moment that has developed in reflexive production cultures. Not least, critique must contend with economistic, postfeminist sensibilities, and individualistic sexualized mythologies, which endure across the generations, circulating among professionals as much as the broader reading public, and lent justification through close associations with their passion for music. That is, "artistic critique" overrides "social critique", in Boltanski and Chiapello's (2005) terms. Broadly, popular music studies requires more textured accounts of intermediation within commercial music worlds beyond the translation of inequalities into objects for consumption, towards the perpetuation and legitimation of unequal production cultures - as they grow increasingly reflexive, complex and hybridized with other industries.

My discussion of this critical moment does not explain how change occurs through critique. Rather, it helps sensitize researchers to the reflexive institutional environment of press, PR, policy and practice in which critique takes place, showing ways in which it might be resisted and the status quo justified. My fourfold thematic analysis gives indications for future research. First, consider the representation of intermediary and support work: who counts, how such work is shaped by production and consumption relations, and what kind of collective imagination is possible. Clearly issues of inequality, exclusion and exploitation are hardly limited to music industries. Nonetheless, the specific aestheticinstitutional environments that appear to enable such issues to persist, despite the professed inclusive and egalitarian values of this group of workers, remains to be adequately accounted for. Second, where recognition of structural issues meets 
individualized responses, how are assumptions about the nature of inequality situated, discursively and materially? This article has emphasised gender. If intersections with class are latent, especially in relation to internships, race and ethnicity, there are more glaring absences here. Equally, beyond the present study's UK focus, there is a need to situate such accounts in comparative national contexts (cf. De Boise 2017), exploring how the gendered terrain of political discourse and institutional variation shapes specific modes of cultural production.

The feminist project of restoring women and other marginalized subjects at the heart of music histories (cf. Parsons 1988; Reddington 2012; Strong 2011) becomes increasingly urgent in the context of intergenerational injustice, my third theme, in terms of who (continues to) occupy which positions of power. Rather than multiplying and diversifying existing heroic narratives, such projects can reveal, discursively and genealogically, the institutionalized links between past and present for industrial (and not just cultural) histories: how values and attitudes formed through participation (production, consumption and intermediation) in 'youth' popular culture are carried into, and shape expectations about, the 'postyouth' contexts of more formal professional life (Bennett 2013). Longitudinal questions of persistent inequality might thus be posed more productively: in a less epochal manner; using a more intersectional approach; acknowledging experiences of ageing; situated culturally, in relation to specific music styles and socialities. Finally, epistemic injustices have arisen regarding, on the one hand, what is known by whom about inequalities and, on the other, who occupies positions of expertise. In this, the need to intervene in (absent) knowledge and (quantitative) data production on popular music inequality issues remains urgent (cf. Wreyford and Cobb 2017), as does challenging positivist notions of simply improving industry transparency.

The debates foregrounded here, over what inequalities exist, why, and how they might be challenged, signal industry's increasing reflexivity. Perhaps this presents a challenge of professional legitimacy for popular music studies, amid assumptions that trade media reporting provides more up-to-date understanding and accurate analysis of industry issues (Wilkinson and Merle, 2013). Nonetheless, we still know little about how such information is circulated, evaluated or responded to by music professionals themselves. This article's pragmatist approach demonstrates the continued urgency of critical scholarship into precisely these questions.

\section{Endnotes}

1 To preserve anonymity, all interviewees' names were changed and roles approximated.

\section{Acknowledgements}

This article has benefited enormously from comments from two anonymous reviewers, as well as close reading from the editors of the special issue, to whom I am hugely grateful. Many thanks also to Pam Burnard for encouraging me to develop some initial ideas and material, and to Rachel O'Neill, Natalie Wreyford and Sally-Anne Gross for reading much earlier drafts and suggesting things to read. 


\section{References}

\section{Bibliography}

Abrahamian, A.A. 2017. The problem isn't sex, it's work. Buzzfeed News, 6 December. https://www.buzzfeed.com/atossaaraxiaabrahamian/the-problemisnt-sex-its-work?utm term=.ouvz7qZk5\#.helJAgodO Accessed: 21 January 2018.

Adkins, L. and Skeggs, B. 2004. Feminism After Bourdieu. Oxford: Blackwell. Ahmed, S. -

2012. On Being Included: Racism and Diversity in Institutional Life. Durham and London: Duke University Press.

2015. Sexism: A Problem with a Name. New Formations. 86: 5-13.

Almeida, R.G. 2015. Swimming with sharks: Sexual predators in the music industry. Vice: Broadly, 5 October.

https://broadly.vice.com/en_us/article/swimming-with-sharks-sexual-predatorsin-the-music-industry Accessed: 21 January 2018.

Baker, L. 2016. The challenge of organising a gender-balanced conference in the music industry. Huffington Post. http://www.huffingtonpost.co.uk/larabaker/gender-balanced-music-industry b 13555434.html Accessed: 21 January 2018.

Barnett, K. 2014. Record Men: Talent Scouts in the U.S. Recording Industry, 1920-1935. In D. Johnson, D. Kompare and A. Santo Eds. Making Media Work: Cultures of Management in the Entertainment Industries. New York: New York University Press: 113-142.

BBC. 2017. Harvey Weinstein timeline: How the scandal unfolded, BBC News, 20 December, http://www.bbc.co.uk/news/entertainment-arts-41594672 Accessed: 12 January 2018.

Bennett, A. 2013. Music, Style and Aging: Growing Old Disgracefully? London: Bloomsbury.

Bennett, T. -

2015. Learning the music business: Evaluating the "Vocational Turn" in Music Industry Education. London: UK Music. https://www.ukmusic.org/skillsacademy/music-academic-partnership/map-collaborative-research/learningthe-music-industry/ Accessed: 22 January 2018.

2018a. "Essential - Passion for Music": Affirming, Critiquing and Practicing Passionate Work in Creative Industries. In L. Martin and N. Wilson Eds. The Palgrave Handbook of Creativity at Work. London: Palgrave: 431-459.

2018b. Towards "Embedded Non-creative Work"? Administration, Digitisation and the Recorded Music Industry. International Journal of Cultural Policy. Online first. DOI:10.0.4.56/10286632.2018.1479399

Bernard, J. 2016. Is the future of the British music industry really so white? The Guardian, 16 March. https://www.theguardian.com/music/2016/mar/16/is-thefuture-of-the-british-music-industry-really-so-white Accessed: 12 January 2018.

Bolin, G. 2016. Passion and Nostalgia in Generational Media Experiences. European Journal of Cultural Studies 19 (3): 250-264.

Boltanski, L. and Chiapello, È. 2005. The new spirit of capitalism. London: Verso. Brady, A. 2016. Taking Time between G-string Changes to Educate Ourselves: Sinéad O'Connor, Miley Cyrus, and Celebrity Feminism. Feminist Media Studies 16 (3): 429-444.

Caldwell, J.T. 2008. Production Culture: Industrial Reflexivity and Critical Practice in Film and Television. Durham: Duke University Press. 
CC Skills. 2011. The Music Blueprint. London: Creative and Cultural Skills. https://ccskills.org.uk/downloads/1319716452-Music-Blueprint-

Web 267 11.pdf Accessed: 1 August 2018.

Cloonan, M. 2007. Popular Music and the State in the UK: Culture, Trade or Industry? Aldershot: Ashgate.

Cloonan, M. and Hulstedt, L. 2013. Looking for Something New: The Provision of Popular Music Studies Degrees in the UK. IASPM@Journa/ 3 (2): 63-77.

Cluley, R. 2013. Why Producers of Music use Discourses of Consumption (and Why We shouldn't think that makes Them Prosumers). Arts Marketing: An International Journal 3 (2): 117-130.

CMU Editorial. 2014. Blurred Lines: Does pop have a misogyny problem? Complete Music Update, 16 May. http://www.completemusicupdate.com/article/blurred-lines-does-pop-have-amisogyny-problem/ Accessed: 12 January 2018.

Conner, T. and Jones, S. 2014. Art to Commerce: The Trajectory of Popular Music Criticism. IASPM@Journal 4 (2): 7-23.

Conor, B. 2014. Gurus and Oscar Winners: How-to Screenwriting Manuals in the New Cultural Economy. Television \& New Media 15 (2): 121-138.

Conor, B., Gill, R. and Taylor, S. Eds. 2015. Gender and Creative Labour. Oxford: Wiley-Blackwell.

Creative Society. 2015. Fair Access Principle. http://www.thecreativesociety.co.uk/wp-content/uploads/2015/04/Fair-AccessPrinciple-final-version-editable.pdf Accessed: 12 January 2018.

Dagens Nyheter. 2017. 2192 women in the Swedish music industry behind appeal against sexism. Dagens Nyheter, 22 November.

https://www.dn.se/kultur-noje/2192-women-in-the-swedish-music-industrybehind-appeal-against-sexism/ Accessed: 1 August 2018.

Dannen, F. 1990. Hit Men: Power Brokers and Fast Money Inside the Music Business. New York: Random House.

DCMS.

2008. DCMS Equality Scheme 2007-2010. London: DCMS

2015. Creative Industries Economic Estimates, January 2015. London: DCMS.

de Boise, S. 2017. Tackling Gender Inequalities in Music: A Comparative Study of Policy Responses in the UK and Sweden. International Journal of Cultural Policy. Online first. DOI: 10.1080/10286632.2017.1341497

Ducker, E. 2013. Q\&A: Veteran music video director Diane Martel on her controversial videos for Robin Thicke and Miley Cyrus. Grantland, 26 June. http://grantland.com/hollywood-prospectus/qa-veteran-music-video-directordiane-martel-on-her-controversial-videos-for-robin-thicke-and-miley-cyrus/ Accessed: 1 August 2018.

Edwards, L. and M. Piezcka. 2013. Public Relations and 'its' Media: Exploring the Role of Trade Media in the Enactment of Public Relations' Professional Project. Public Relations Inquiry. 2 (1): 5-25.

Ellis-Petersen, H. 2016. Brit awards announce voting shakeup after \#BritsSoWhite outrage. The Guardian, 7 November.

https://www.theguardian.com/music/2016/nov/07/brit-awards-announcevoting-shakeup-after-britssowhite-outrage Accessed: 1 August 2018.

Forde, E. 2016. Who are the most powerful people in music? Jay Z? Kanye? Beyoncé? No, it's old white men. The Guardian, 15 February. https://www.theguardian.com/music/musicblog/2016/feb/15/old-white-mendominate-billboard-power-100-list Accessed: 1 August 2018. 
Fraser, N. 2013. Fortunes of Feminism: From State-managed Capitalism to Neoliberal Crisis. London: Verso.

Frith, S. 1983. Rock Biography. Popular Music. 3: 271-277.

Gadir, T. 2017. Forty-seven DJs, Four Women: Meritocracy, Talent and Postfeminist Politics. Dancecult: Journal of Electronic Dance Music Culture 9 (1): $50-72$.

Gill, R. -

2003. Power and the Production of Subjects: A Genealogy of the New Man and the New Lad. The Sociological Review 51: 34-56.

2007. Postfeminist Media Culture: Elements of a Sensibility. European Journal of Cultural Studies, 10 (2): 147-166.

2014. Unspeakable Inequalities: Post Feminism, Entrepreneurial Subjectivity, and the Repudiation of Sexism Among Cultural Workers. Social Politics 21 (4): 509-528.

2016. Post-postfeminism?: New Feminist Visibilities in Postfeminist Times. Feminist Media Studies 16 (4): 610-630.

2017. The Affective, Cultural and Psychic Life of Postfeminism: A Postfeminist Sensibility 10 years on. European Journal of Cultural Studies 20 (6): 606626.

Gill, R., Kelan, E. and Scharff, C.M. 2016. A Postfeminist Sensibility at Work. Gender, Work \& Organization 24 (3): 226-244.

Gross, S.A. and Musgrave, G. 2017. Can Music Make You Sick? A Study into the Incidence of Musicians' Mental Health. Part 2: Qualitative Study and Recommendations. London: MusicTank. http://www.musictank.co.uk/wpcontent/uploads/woocommerce_uploads/2017/10/Can-Music-Make-You-SickPart-2-Qualitative-Study.pdf Accessed: 1 August 2018.

Haynes, J, and Marshall, L. 2018. Reluctant Entrepreneurs: Musicians and Entrepreneurship in the 'New' Music Industry. The British Journal of Sociology. 69 (2): 459-482.

Hesmondhalgh, D. and Baker, S. 2015. Sex, Gender and Work Segregation in the Cultural Industries. The Sociological Review 63 (S1): 23-36.

HMRC. 2014. Brit Awards record labels face the music on unpaid interns. HM Revenue \& Customs. https://www.gov.uk/government/news/brit-awards-recordlabels-face-the-music-on-unpaid-interns Accessed: 12 January 2018.

Jennings, R. and Gardner, A. 2012. 'Rock on': Women, Ageing and Popular Music. Aldershot: Ashgate.

Jones, R. -

2016a. How to be a boss woman in the music industry. Medium. https://medium.com/@JonesJourno/how-to-be-a-boss-woman-in-the-musicindustry-a12e9a82f6ff Accessed: 21 January 2018.

2016b. How can the music industry tackle its diversity issues? Music Business Worldwide, May 24. https://www.musicbusinessworldwide.com/can-musicindustry-tackle-diversity-problem/ Accessed: 21 January 2018.

2018. The music business's gender pay gap is embarrassing and uncomfortable. It's time for change. Music Business Worldwide, April 4. https://www.musicbusinessworldwide.com/the-music-businesss-gender-pay-gap-isembarrassing-and-uncomfortable-its-time-for-change/ Accessed: 6 August 2018.

Leonard, M. 2014. Putting Gender in the Mix: Employment, Participation, and

Role Expectations in the Music Industries. In C. Carter, L. Steiner and L.

McLaughlin Eds., The Routledge Companion to Media and Gender. London: Routledge: 127-136.

Lindvall, H. - 
2010. Behind the music: the gender gap shows no signs of closing. The Guardian, May 7.

https://www.theguardian.com/music/musicblog/2010/may/07/behind-themusic-gender-gap Accessed: 12 January 2018.

2013. Why unpaid interns are bad for the music industry. The Guardian, August 15. https://www.theguardian.com/media/2013/aug/15/unpaidinterns-music-industry Accessed: 12 January 2018.

M. 2017. Gender gap narrows at PRS For Music. M, December 19.

https://www.m-magazine.co.uk/news/gender-gap-narrows-prs-music/ Accessed: 21 January 2018.

Mackenzie, J. 2017. Rape and abuse: The music industry's dark side exposed. $B B C$. http://www.bbc.co.uk/news/entertainment-arts-42368544 Accessed: 21 January 2018.

Mannheim, K. 1952. Essays on the Sociology of Knowledge. London: Routledge \& Kegan Paul.

McRobbie, A. -

1990. Settling Accounts with Subcultures: A Feminist Critique. In S. Frith and

A. Goodwin Eds. On Record: Rock, Pop and the Written Word. London:

Routledge: 66-80.

2008. The Aftermath of Feminism: Gender, Culture and Social Change.

London: Sage.

2016. Be Creative: Making a Living in the New Culture Industries. Cambridge: Polity.

Mort, F. 1996. Cultures of Consumption: Masculinities and Social Space in Late Twentieth-Century Britain. London: Routledge.

Negus, K. 1992. Producing Pop. London: Edward Arnold.

Newman, M. 2017. Why the \#MeToo Movement Could Have Chilling Effect for Women in Music Industry. Billboard, 14 December. https://www.billboard.com/articles/business/8070562/metoo-movementwomen-music-industry-impact Accessed: 12 January 2018.

O'Brien, D. and Oakley, K. 2015. Cultural Value and Inequality: A Critical Literature Review. London: AHRC.

Oakley, K. and O'Brien, D. 2016. Learning to Labour Unequally: Understanding the Relationship between Cultural Production, Cultural Consumption and Inequality. Social Identities 22 (5): 471-486.

Parsons, P.R. 1988. The Changing Role of Women Executives in the Recording Industry. Popular Music and Society 12 (4): 31-42.

Phipps, A., Ringrose, J., Renold, E. and Jackson, C., 2018. Rape Culture, Lad Culture and Everyday Sexism: Researching, Conceptualizing and Politicizing New Mediations of Gender and Sexual Violence. Journal of Gender Studies. 27 (1): 1-8.

Reddington, H. 2012. The Lost Women of Rock Music: Female Musicians of the Punk Era. $2^{\text {nd }}$ ed. Sheffield: Equinox.

Redmond. S. 2017. What the Hell's Happening to Music's Trade Press? (And What Does it Mean for the Rest of Us?). Music business Worldwide, November 27. https://www.musicbusinessworldwide.com/hells-happening-musics-tradepress-mean-rest-us/ Accessed: 17 April 2018.

Strong, C. 2011. Grunge, Riot Grrrl and the Forgetting of Women in Popular Culture. The Journal of Popular Culture 44 (2): 398-416. 
Taylor, M. and O'Brien, D. (2017). 'Culture is a Meritocracy': Why Creative Workers' Attitudes may Reinforce Social Inequality. Sociological Research Online 22 (4): 27-47.

Wilkinson, K.T. and Merle. P.F. 2013. The Merits and Challenges of Using Business Press and Trade Journal Reports in Academic Research on Media Industries. Communication, Culture \& Critique 6: 415-431.

Winch, A., J. Littler and Keller, J. 2016. Why 'Intergenerational Feminist Media Studies'? Feminist Media Studies 16 (4): 557-572.

Wreyford, N. and Cobb, S. 2017. Data and Responsibility: Toward a Feminist Methodology for Producing Historical Data on Women in the Contemporary UK Film Industry. Feminist Media Histories 3 (3): 107-132.

Zadeh, J. 2016. Why We're Talking About Music and Mental Health This Week. Vice: Noisey http://www.vice.com/en_uk/read/noisey-guide-to-music-andmental-health Accessed: 12 January 2018.

\section{Videography}

Miley Cyrus, 2013. "Wrecking Ball". Online video. Available at: https://www.youtube.com/watch?v=My2FRPA3Gf8 Last accessed 6 August 2018

Robin Thicke 2013. "Blurred Lines ft. T.I., Pharrell". Online video.

\section{Web Sources}

Girls I Rate, n.d. https://www.girlsirate.com/ Accessed: 12 January 2018.

Let's Be The Change. n.d. http://www.letsbethechange.co.uk/ Accessed: 21 January 2018.

shesaid.so, n.d. http://www.shesaid.so/ Accessed: 12 January 2018.

UK Music -

n.d. Equality \& Diversity. UK Music https://www.ukmusic.org/equalitydiversity/ Accessed: 12 January 2018.

2016. Diversity Survey Results 2016. UK Music http://www.ukmusic.org/equality-diversity/uk-music-diversity-survey-results/ Accessed: 12 January 2018.

2017. Measuring Music: 2017 Report. London: UK Music.

Women in Music, n.d. https://www.nbmevents.uk/womeninmusic/. Accessed: 12 January 2018.

\section{Interviews}

Alan. 2014. Interviewed by Toby Bennett, London, 23 January. 